\title{
Maximizing Strategic Alliances in the Multi-Sided Platform Firms
}

\author{
Adhi Setyo Santoso a,b,* and Sari Wahyuni ${ }^{\mathrm{b}}$ \\ ${ }^{a}$ School of Business, Department of Business Administration \\ President University \\ Cikarang, West Java 17550, Indonesia \\ adhi.setyo.santoso@gmail.com \\ ${ }^{\mathrm{b}}$ Faculty of Economics and Business, Graduate School of Management \\ Universitas Indonesia \\ Depok, West Java 16424, Indonesia \\ sari.whyn@gmail.com
}

\begin{abstract}
The growth of multi-sided platform (MSP) firms, especially those with high Internet utilization such as Uber, Tokopedia, Go-Jek as well as other sharing economy firms, started to catch the attention of strategic management scholars. Since multi-sided platforms have more than one distinct user side with various role in the business ecosystem, the strategic alliances between the MSP and its platform members may play a significant role in increasing the user base as well as the value of the platform itself. However, there are still few researches that discuss the strategic alliances within the MSP. For this reason, this conceptual article aims at mapping the strategic alliances literature relevant to the MSP context through in-depth literature review. Two case analyses from high growth MSP firms in Indonesia are presented to explain this phenomenon.
\end{abstract}

JEL Classifications: $03, Y 8$

Keywords: multi-sided platform, strategic alliances, resource-based view, network effects, platform strategy, innovation, technological change, sharing economy 
I.

INTRODUCTION

In the current information era, interconnection is growing at a massive scale. Instead of creating some IT products, digital startups tend to build platforms that connects one or more social group (Alstyne, Parker, and Choudary, 2016). Commonly, these platforms can act as intermediaries with marketplace function, where suppliers sell their products or services directly (Hagiu and Wright, 2013, 2015; Santoso and Erdaka, 2015). The examples of marketplace platform firms are Tokopedia, Go-Jek, and Uber (Moore, 2017). The platform firms can also play role as transactional intermediaries entity with reseller function, where the platform purchases products or services from the suppliers and then sell them to platform customers (Hagiu and Wright, 2013, 2015; Santoso and Erdaka, 2015). The examples of this kind of firms are Lazada, Blibli, and Zalora (Moore, 2017). Hagiu and Wright (2014) argue that marketplace function is suitable for products or services that satisfy several criteria. Firstly, significant information should be provided by the suppliers on how to market these products and services in the most effective way. Secondly, their prices and marketing activities should have limited spillovers other products or services. Thirdly, they should have long-tail characteristic. Lastly, they should be provided by late stage entrepreneurs. On the other hand, reseller function is suitable for those products or services with opposite criteria. The mix of the above criteria enables platforms to implement a hybrid function, with both reseller and marketplace functions. The hybrid mode includes more than one party such as buyers, micro-entrepreneurs (suppliers), payment gateways, and more. For this reason, those platforms is considered as Multi-Sided Platform (MSP). A large number of MSP firms have been created in the past few years, especially in regions with a high growth of Internet access.

In a strategic perspective, MSP has specific characteristics. The strategic role is not only held by the managers of MSP firm but also by the micro-entrepreneurs supplying on the platform. Intuitively, buyers have a reason to use the platform thanks to the products or services delivered by the micro-entrepreneurs. Previous studies mentioned that a MSP even makes extra efforts to keep the 'marquee' users in the platform in order to attract users from different groups (Eisenmann, Parker, and Alstyne, 2006). Thus, in term of strategic alliances, the MSP firm is not only making alliances with other firms but also including in its alliances portfolio a number of micro-entrepreneurs as one of the platform users.

The number of micro-entrepreneurs grows sporadically based on the network effects (Eisenmann, 2006). In this context, the strategic alliances are different from others. The strategic alliances between MSP firms and its micro-entrepreneurs are commonly managed by intermediary systems with less direct interactions among them. This situation creates some challenges for the MSP firms since they do not have direct control on those platform elements with a strategic role. Furthermore, there are few exclusive arrangements in this kind of alliances. Since there are several competing platforms that micro-entrepreneurs are able to participate in and utilize those platforms to market their products and services, it is quite challenging to maximize the alliances with the micro-entrepreneurs to enhance MSP firms' performance and achieve competitive advantages (Eisenmann, 2011).

In order to address this challenge, this article will explore the previous studies related to MSP strategy and strategic alliances with the complementor side of the 
platform or business ecosystem. The complementor itself can be any type of users in the platform including customers, suppliers, as well as support users such as payment system providers (Gawer and Cusumano, 2008). The previous literature on MSP strategies discussed in this article covers business models (Campbell-Kelly et al., 2015; Oestreicher-Singer and Zalmason, 2013), network effects (Parker and Alstyne, 2005), platform envelopment (Eisenmann, 2011), and growth strategy (Eisenmann, 2006). Moreover, previous strategic alliances studies include several topics such as strategic alliances with suppliers and customers (Siew-Phaik et al., 2013), effect of IT capabilities in strategic alliances (Lioukas et al., 2016), alliances portfolio creation and firm innovativeness (Golonka, 2015), strategic alliances in small business perspective (Street and Cameron, 2007), and franchise (Combs et al., 2011). While strategic alliances have been a mature topic in the strategic management area for the past decades, there are still limited studies that explores the strategic alliances between platforms and their users within a platform ecosystem. For this reason, this study offers an in-depth literature review in the area of strategic alliances within the MSP context.

In this article, we present two case analyses of relatively new MSP firms in Indonesia, namely Go-Jek and Tokopedia, to provide an insight on the strategic alliances between digital platforms and their platform members. In these analyses, a discussion concerning the implications for the industries affected by the two MSP firms is also provided. We use these analyses to discuss theoretical implication for strategic alliances and other related area. The article is structured as follows. It begins with an examination of the concept of MSP strategies as well as of strategic alliances topics related to the MSP context. The review is followed by case analyses that include the recent phenomena of MSP in an emerging country, Indonesia. Before the conclusion, the theoretical implications and analyses as well as the research gaps and future research opportunities are also discussed.

\section{REVIEW OF LITERATURE ON MSP STRATEGY AND STRATEGIC ALLIANCES}

The strength of MSP firms lays on the direct interaction between more than one distinct sides, each of them affiliated with the platform (Hagiu, and Wright, 2014). These characteristics produce network effects that enable MSP firms to scale up the customer base as the platform's asset base with significant increases (Eisenmann, 2011). However, while the resource-based view (RBV) is the dominant paradigm in the current era of strategic management research, the strategy scholars still have not done much effort in aligning RBV and MSP. Nonetheless, if in RBV perspective the customer base is the valuable resource of the firm (Barney, 1986; Dierickx and Cool, 1989), this is also relevant for platforms, where accumulating a large customer base can produce larger value (Peteraf and Bergen, 2003).

\section{A. Multi-sided Platform Strategy}

MSP has been defined as a business center with several fundamental characteristics that differ from a conventional single business. First, it has two or more customer types. Second, there are indirect externalities among the customers within the platform. Third, there is a need for intermediary roles to internalize the interconnections between the 
different sides of the platform (Evans, 2003). The cross-group interdependencies within the platform create both challenges and opportunities. For instance, a common challenge for a MSP in early stage is the "chicken-and-egg" problem, since each side will not participate in the platform without enough customers on the other side. Attracting multiple sides at the same time is obviously a costly and difficult thing to do. MSP firms should make the strategic decision to create an alliance with any side as the starting point and then grow the other side by utilizing the network effects (Caillaud and Jullien, 2003).

\section{Business model for MSP: smartphone OS case}

This kind of challenge can be overcome with certain strategic approaches such as resources orchestration. The different customer group can be considered as valuable assets that should be structured through business model creation in order to do configuration process toward competitive advantage (Sirmon et al., 2011). CampbellKelly et al. (2015) show that business model in smartphone MSP, especially Google's Android and Apple's iOS, are able to solve the "chicken-and-egg" problem and to sustain their momentum despite using pretty different strategies. At the beginning, Apple's iOS, first mover in smartphone industry with compelling mobile applications, choose to pursue a differentiation strategic positioning to attract the customer side with very innovative features supported by Apple's existing platform such as iTunes Music Store, close-source code, and exclusive strategic alliance with a single telecommunication provider, AT\&T. This approach led to high performance because Apple managed to balance prospecting firm characteristics with leading technology, IT, marketing, and management capabilities (Desarbo, Benedetto, and Sinha, 2005). After Apple succeeded in attracting 6 million customers worldwide in mid-2008, the company started to invite third-party developers to join another side of the platform (Krazit, 2008a). In term of profits, Apple relied much on selling the handset as main revenue stream.

Apple's iOS closest competitor, Google's Android, choose an opposite path. At the beginning, Google's Android entered the smartphone market as a latecomer, when Symbian, RIM, and Apple already had significant shares of the smartphones' market. Thus, Google's Android attracted first as many actors as possible at the supply side of the platform, such as handset makers and third-party developers with free operating system license. As a result, Google's Android started to match the Apple iOS in 2009, when Motorola created their first Android-based smartphone (Mossberg, 2010). Later, other handset manufacturers and third-party developers produced high-quality devices and applications, compelling enough to attract a large number of customers. In contrast to Apple, Google's Android relied on advertisement to achieve a sustainable profit. However, the two business models shares some commonalities that allow them to maintain a sustainable competitive advantage: attracting and even making strategic alliances with one or more of the MSP element in smartphone ecosystem such as consumers, telecommunication providers, third-party app store, and third-party developers. The main difference between their strategies is the side to be subsidized in order to attract the other sides, and which side takes the role of main revenue creator. 


\section{Business model for MSP: content vs. community}

Oestreicher-Singer and Zalmason (2013) study shows that the business model is very critical in the social age. The authors conducted a research by using last.fm music platform and find out that the willingness to pay for freemium (free and premium subscriptions) business model is related to the community participation level of certain user. A higher level of participation within the community increases the platform user's willingness to pay. In this context, the community participation level has more significant impact than the volume of content consumption.

The study compares and contrasts the user's activity in the platform based on communities of practices (Wegner, 1998), participation levels (Kim, 2000), social technolographics tool (Bernoff and Li, 2008), and Reader-to-Leader Framework (Preece and Schneiderman, 2009). In the technolographics tool perspective, it is shown that the user who does content tagging, voting, and rating will be more willing to pay than users who only read content and create a user page. Furthermore, users who publish user-generated-content have more tendency to subscribe for premium service rather than users who only post comments, tag content, and read content. In term of free usage service duration, users with high community participation only use free service for a shorter time before they purchase the premium subscription package. Online community leaders also tend to have shorter time in using free service.

Based on the findings above, the freemium business model is suitable for MSP firms that, instead of using social media merely as an offline soft marketing substitute, integrate and utilize social media strategically for purchase as well as consumption experience. Thus, in term of revenue sustainability, the freemium business model attracts the customer side with not only the supplier side, but also with the existing customer side through "power user".

\section{Network effects}

Both the literature presented above discuss a business model adopted by MSP firms that makes use of network effects. Network effects originally refer to products and services that value increases with the number of users using them (Saphiro and Varian, 1999). The network effects create customer lock-in and increase switching costs, crucial features for MSPs' model as this raises the entry barrier against the competitors as well as decreases the customer churn rate (Eisenmann, 2006).

Network effects are considered as the most essential variable in the economic perspective (Rochet and Tirole, 2003; Evans, 2003). In this perspective, network effects are divided in two categories, direct and indirect network effects (Hagiu and Wright, 2014). Direct network effect increases the value of the platform when there is a great number of users from same-side of the platform, such as the case of telephones. On the other hand, indirect network effect is defined as cross-group network effect where the number of participants on any side enhances the benefit for the participant on the other sides. Based on this nature, the research from the industrial organization economics perspective often lies on the issue of bringing multiple sides to the platform (Rochet and Tirole, 2003; Evans, 2003), avoiding the "chicken-and-egg" problem (Caillaud and Jullien, 2003), and also adopting a pricing strategy that subsidizes one side in order to attract another side on the platform (Van Alstyne and Parker, 2005). 
Parker and Alstyne (2005) propose a two-sided network effects model arguing three things about network economics for the MSP firm perspective. First, the MSP firms can rationally choose the freemium business model and invest on some free products for the retention of the customers even in situations where there are no competitors in the market. The objective for taking this initiative is to increase the demand of the complementary premium-goods. Since the demand is increasing, the revenue obtained from this initiative is not only able to cover the investment on free products but also to grow the existing revenue significantly thanks to network effects. Second, within the two-sided platform, each side has distinct roles and characteristics. One of the sides can be subsidized through discounting or free distribution. The subsidized side is the one with a high-level of externality benefits that can increase the demand of the other side. Third, the product coupling from one side to another increases consumer welfare even in a situation where the MSP firm tries to do so in order to increase its profits.

\section{MSP's firm strategy: platform envelopment}

Multi-sided markets mentioned above are a good target for strategic envelopment (Eisenmann, 2011). The platform envelopment itself is a strategic approach to enter the platform market without relying on a Schumpeterian innovation that offers significant functionality changes. This approach utilizes its own functionality combined with the target platform functionality and even the target's network effects. The combination creates better value and leaves the target's users without a reason to stay with the incumbent platform in term of the products or service features. Hence, the MSP firm can overcome the entry barrier from target platform network effect and switching cost from its user perspective.

There are several envelopment typology attacks for MSP firms. First, the envelopers can take the role of complements to the target. Second, the envelopers can also position themselves as weak substitutes to the target. Third, they can take an approach with functionally unrelated features to the target.

\section{Growth strategy for internet firms}

As mentioned above, the customer base is the main strength and objective of MSP firms. Therefore, user base growth is the significant goal to achieve in the shortest possible time. Eisenmann (2006) conducts a research on the determinant factors of the intensity of the investment of the Internet company growth and its relationship to longterm performance. The study finds that the first mover Internet firm has much higher expenses in upfront marketing than latecomer Internet firms. In this context, winnertakes-all (WTA) markets are defined as markets with few survivors and high concentration levels. The participants in these markets tend to pursue accelerated growth strategies. Therefore, they encourage heavy investments in customer acquisition efforts. The firms in new markets also tend to invest on customer acquisition, ex ante, at levels that maximize long-term performance, ex post. From the data, it is shown that they are more likely to underinvest on customer acquisition in IPO-year than overinvest on it. 
Interestingly, high-return Internet firms have lower spending in early IPO-year customer acquisition efforts than those with lower performance, even though this kind of firms have winner-takes-all attributes such as strong network effects, static economics of scale, as well as high customer switching cost. There are two plausible reasons regarding this phenomenon. First, the managers of this kind of company may systematically underestimate the strength of heavy customer acquisition investment in increasing returns. However, the second reason is related to their performance, as having enjoyed 'instant scalability' enabled them to expand without increasing the production or delivery activity (Liebowitz and Margolis, 2001). Nonetheless, high amount of investment at the early growth stage of Internet firms is economically rational as reducing marketing budget may reduce the outcome as well.

The summary of multi-sided platform strategy discussed above is presented in Table 1.

Table 1

The summary of multi-sided platform strategy

\begin{tabular}{|c|c|c|c|c|c|}
\hline $\begin{array}{l}\text { MSP } \\
\text { Strategy } \\
\text { Context }\end{array}$ & $\begin{array}{c}\text { Campbell- } \\
\text { Kelly et al. } \\
\text { (2015) }\end{array}$ & $\begin{array}{c}\text { Oestreicher- } \\
\text { Singer and } \\
\text { Zalmason } \\
(2013)\end{array}$ & $\begin{array}{c}\text { Parker and } \\
\text { Alstyne } \\
(2005)\end{array}$ & $\begin{array}{c}\text { Eisenmann et al. } \\
\text { (2011) }\end{array}$ & $\begin{array}{l}\text { Eisenmann } \\
\quad(2006)\end{array}$ \\
\hline $\begin{array}{l}\text { Resource- } \\
\text { Based View }\end{array}$ & $\mathrm{V}$ & $\mathrm{V}$ & & $\mathrm{V}$ & $\mathrm{v}$ \\
\hline $\begin{array}{l}\text { Business } \\
\text { Model }\end{array}$ & $\mathrm{v}$ & $\mathrm{V}$ & $\mathrm{V}$ & & \\
\hline $\begin{array}{l}\text { Platform } \\
\text { Competition }\end{array}$ & $\mathrm{V}$ & & $\mathrm{V}$ & $\mathrm{v}$ & \\
\hline $\begin{array}{l}\text { Market } \\
\text { Penetration } \\
\text { Strategy }\end{array}$ & $\mathrm{V}$ & & $\mathrm{V}$ & $\mathrm{V}$ & \\
\hline $\begin{array}{l}\text { Strategic } \\
\text { Alliances }\end{array}$ & $\mathrm{v}$ & & $\mathrm{v}$ & & \\
\hline $\begin{array}{l}\text { Growth } \\
\text { Strategy }\end{array}$ & $\mathrm{V}$ & & $\mathrm{V}$ & & $\mathrm{V}$ \\
\hline
\end{tabular}

\section{B. Strategic Alliances Topics related to MSP Context}

The studies on MSP strategy discussed above are mostly based on a RBV perspective that points at user base as the vital resources to create value. The user base itself can be created at each sided. Since MSP has several distinct sides that interact with each other in the platform, it is common for MSP to initiate strategic alliances with one of the sides in order to attract the other sides to join the platform and scale up the platform value (Alstyne and Parker, 2005; Eisenmann, 2006). There are several models of strategic alliances from past literatures including hierarchical relations, joint ventures, 
equity investments, cooperatives, R\&D consortia, strategic cooperative agreements, cartels, franchising, licensing, subcontractor networks, industry standards groups, action sets, and market relations (Todeva and Knoke, 2005). Those that are related to another entity within the business ecosystem may work for attracting the user base from a certain side to join the MSP.

From the micro-entrepreneurs' perspective at the supplier side, the flexible nature of MSP makes them less dependent from the platform that conducted strategic alliance with them. They can join or leave the platform at any time. In the previous study, less dependency on partners has shown to generate higher organizational performance since it provides the flexibility to direct the organization learning (Sukoco, 2016). Thus, in the MSP context, the performance of the supplier side of the platform will be higher in this setting. In return, it contributes to the overall performance of MSP firms. The convergence-learning mode can be implemented as well since the partnership between MSP firms and their users has great asymmetrical dependencies (Sukoco, 2015).

\section{Strategic alliances with suppliers and customers}

Strategic alliances with another entity within the business ecosystem have been discussed in previous literatures. Siew-Phaik et al. (2013) explore the influencing factors of strategic alliances with customers and suppliers. It is shown that there are several findings between the firms and their suppliers as well as customers in term of strategic alliances within the manufacturing industry. First, the relationship between alliances motives and the environment is significant for alliances with suppliers. Second, the relationship between relational capital and alliances motives as well as opportunistic behavior is shown to be significant in alliances with customers. Third, the relationship between interdependence and asset specificity is significant for the alliances with customers. Fourth, the relationship between interdependence and opportunistic behavior is significant with the suppliers.

\section{Effects of IT capabilities for strategic alliances}

Most MSP firms nowadays maximize the use of information technology to create as well as capture the value, or support routines. Lioukas et al. (2016) find that firms that embody good IT capabilities can derive better value in strategic alliances performance. However, the effects vary in accordance to the alliance characteristics. In particular, for alliances with a non-equity governance structure and those with high level of interdependence between partners, IT capabilities are very valuable.

In this context, IT capabilities include IT managerial capabilities that enable the firm to identify and implement IT solutions for alliance purposes. These capabilities are developed through the combination of both IT-related and alliance-related knowledge within the firm. It is necessary to have an idiosyncratic knowledge and a comprehensive knowledge exchange between parties. In routines, these capabilities help the firm achieve alliance objectives through the exchange of a significant amount of information between parties in the scope of organizing and coordinating alliance tasks. 


\section{Complexity of alliance portfolio and firm's innovativeness}

One of the strategic alliances objectives is the firm's innovativeness as measurement of the alliances performance. Golonka (2015) conducts a research within this area and focuses on the alliance portfolio creation and its impact on the complexity of alliance portfolio as the antecedent of the firm's innovativeness. The alliance portfolio creation consists of cooperation forming (market-focus strategy and relationship-focus strategy) and manager's proactiveness and trust for the alliance partner.

The results show that managers who proactively search and select the strangers within the market as alliance partner (market-focused cooperation strategy) have a positive impact on the complexity of alliance portfolio in term of functions, number of ties, governance complexity, and geography. In contrasts, relying on acquaintances, friends, and their recommendation for selecting the partners and alliances may decrease its complexity. Interestingly, the higher complexity of the firm's alliance portfolio makes the firm's innovativeness increase. The complexity leads to alliance diversity in term of downstream-upstream, vertical-horizontal, scale-link, exploration-exploitation, and also formal-non-formal. The diversity allows the firm to have access to broader knowledge, complementary competences, technology, as well as network resources. Hence, this can increase the firm's innovativeness as long as the firm has the ability to manage its portfolio. The research itself is conducted by collecting the data from 146 SME in ICT industry with 4006 alliances portfolio ties.

\section{Strategic alliances in small business perspective}

MSP in emerging markets mostly focus on small businesses and their microentrepreneurs micro-entrepreneurs as the platform side that has strategic role to attract another side to join the platform. The small business research has been growing in the recent years and focuses on external resources to increase the small business's performance. Street and Cameron (2007) offer a review of the part literature that discusses the utilization of external relationship including alliances, networks, and organizational partnership. Thus, the discussion about strategic alliance in small business perspective includes RBV and resource dependence theories as well.

The antecedents of external relationship process consist of several characteristics such as individual characteristics of the entrepreneur (ethnicity, personal network, individual or collective value, etc.) and of the manager (willingness to learn, selfinterest, etc.), organizational characteristics of the SME and the partner, relationship characteristics, and environmental characteristics. The external relationship process consists of strategy development and planning and relationship management (relationship formation, active participation, trust, and relationship building, and organizational learning). The outcomes of external relationships for small businesses includes organizational development (access to resources and business development), competition and competitive advantage, and performance/success that consists of objective and subjective performance (innovation, adding value, growth, etc.) as well as success in terms of a stated goal (survival, maintaining an alliance, survival, etc.). 


\section{Franchising}

Micro-entrepreneurs within MSP use the system offered by the platform and act as if they were the platform owner. Even though the end products or services vary across the multi-entrepreneurs, the main business process is quite similar. Hence, the concept is close to the franchise. The existing literature on franchise has discussed franchising antecedents, consequences, and moderation as well as mediation factors in matter of franchise.

Combs et al. (2011) reviews the past literatures and identifies the theoretical gaps. The issues regarding antecedent gaps range from franchising motives, resource scarcity approach for franchising decision, property rights allocation, strategic management theory for franchising decision, economic incentives, franchising capabilities development to test the prediction theory for franchising. On the other hand, the issues related to consequences on franchising include synergies between franchised and company owned-outlets, franchisee exit factors, ownership changes effect on franchised outlets' performance, relational exchange theory in franchising, impact of franchisee strategy, moderating role of local markets key attributes between franchising and performances, and mutually beneficial mechanism of franchisors and franchisees.

The summary of strategic alliances related to the MSP context discussed above is presented in Table 2 .

Table 2

The summary of strategic alliances related MSP

\begin{tabular}{|c|c|c|c|c|c|}
\hline $\begin{array}{l}\text { Strategic } \\
\text { Alliances } \\
\text { Context }\end{array}$ & $\begin{array}{l}\text { Siew-Phaik } \\
\text { et al. (2013) }\end{array}$ & $\begin{array}{l}\text { Lioukas et al. } \\
\text { (2016) }\end{array}$ & $\begin{array}{c}\text { Golonka } \\
(2015)\end{array}$ & $\begin{array}{c}\text { Street and } \\
\text { Cameron } \\
(2007)\end{array}$ & $\begin{array}{l}\text { Combs et } \\
\text { al. }(2011)\end{array}$ \\
\hline $\begin{array}{l}\text { Resource- } \\
\text { Based View }\end{array}$ & $\mathrm{V}$ & $\mathrm{V}$ & $\mathrm{V}$ & $\mathrm{V}$ & $\mathrm{V}$ \\
\hline $\begin{array}{l}\text { Alliance } \\
\text { Motives }\end{array}$ & $\mathrm{v}$ & & & $\mathrm{v}$ & $\mathrm{v}$ \\
\hline $\begin{array}{l}\text { Alliances } \\
\text { Outcomes }\end{array}$ & $\mathrm{V}$ & $\mathrm{V}$ & & $\mathrm{V}$ & $\mathrm{V}$ \\
\hline $\begin{array}{l}\text { Alliances in } \\
\text { Small Business }\end{array}$ & & & $\mathrm{v}$ & $\mathrm{v}$ & \\
\hline Franchising & & & & & $\mathrm{v}$ \\
\hline $\begin{array}{l}\text { Alliance } \\
\text { Antecedents }\end{array}$ & & & $\mathrm{v}$ & $\mathrm{V}$ & $\mathrm{v}$ \\
\hline $\begin{array}{l}\text { Alliance } \\
\text { Consequences }\end{array}$ & & $\mathrm{V}$ & $\mathrm{V}$ & $\mathrm{V}$ & $\mathrm{V}$ \\
\hline
\end{tabular}




\section{THE CASE OF STRATEGIC ALLIANCE WITHIN MSP FIRMS: EVIDENCE FROM GO-JEK AND TOKOPEDIA}

This section presents empirical evidence of the implementation of strategic alliances within MSP firms discussed above with two high-growth MSP firms in Indonesia, namely Go-Jek and Tokopedia. Present and future implications for relevant industries are also discussed.

\section{A. Go-Jek}

Go-Jek is the first Indonesian startup firm to have achieved unicorn startup predicate (valuated at \$1 billion or more), on par with Uber and Grab (Raharso and Sia, 2017). Go-Jek application is believed to be the driver of the rapid growth of mobile commerce in Indonesia. It educated the market on fulfilling essential needs by smartphone. The firm was founded in 2011 as a peer-to-peer (P2P) online transportation company that simply operated through a website and a call center. Differently from any firm with outsourcing employment arrangements, MSP firms like Go-Jek treat their platform users who join at the supplier side as strategic alliance partners. Despite the stagnant growth between 2011 and 2014, Go-Jek has adopted in the beginning of 2015 Uber's $\mathrm{P} 2 \mathrm{P}$ online transportation business model, and has since then grown rapidly, evolving from a mere P2P online transportation company to a service platform for every need including hospitality, culinary, cleaning, financial, logistics, auto workshop, entertainment, health, as well as other form of e-commerce sectors. As of 2017, Go-Jek already has 16 different services on their application. This evolution has shown GoJek's ability to maximize strategic alliances with multiple crowd parties by using their platform as a core.

As a pioneer of mobile commerce in the nascent market, Go-Jek needed to solve the "chicken-and-egg" problem to enable multiple parties to have interactions and transactions on their platform. In this matter, Go-Jek has taken an approach similar to Android, focusing on the suppliers' side first, the micro-entrepreneurs, and ensuring its availability to the customer side. When initiating strategic alliances with microentrepreneurs, Go-Jek provided better opportunities for the potential target of microentrepreneurs than any other alternative. For example, during the early growth of their P2P online transportation services, Go-Jek has recruited thousands of motorbike taxi drivers just in a day at the largest soccer stadium in Indonesia, Gelora Bung Karno (Heber, 2015). The drivers were offered better potential income than what they were able to earn from other jobs. Furthermore, there are significant bonuses offered if to those who fulfil certain amount of transaction (Hutabarat, 2015). The general Go-Jek business model for their P2P online transportation services is a profit sharing mechanism with $80 \%$ of the tariff going to the drivers and $20 \%$ of it going to Go-Jek as transaction fee. However, in order to keep a low price to penetrate the market, Go-Jek provides huge subsidies for the customers' side and brings an enormous number of users. As a result, not only conventional motorbike taxi joined as a Go-Jek driver, but other segments such as restaurant waiters, security personnel, and even fresh graduate students from university.

The fundamental growth strategy for Go-jek is to be the first mover. Even though they have capital resources comparable to Uber, their uses of the focus strategy 
on growing P2P online transportation is quite different. Contrary to Uber, Go-Jek uses broad diversification strategy for achieving high growth and creating series of competitive advantages over their direct competitors (Uber and Grab also have a startup unicorn predicate). In every business model innovation, Go-Jek relies on their existing platform and the crowd resources available in the market. Aligned with the concept of Tipping strategy and in particular of platform envelopment (Eisenmann, 2011; Gawer and Cusumano, 2008), Go-Jek searches and acquires neighbor markets that can be entered by some efficient or even little modification in their platform and their existing business model as well as by combining the new functionality from this process with existing ones. They do platform envelopment toward every promising service in the market. The chronological order of Go-Jek diversification strategies is presented in Table 3.

Table 3

Go-Jek selected platform strategies

\begin{tabular}{|c|c|c|c|c|}
\hline $\begin{array}{l}\text { Product / } \\
\text { Service } \\
\text { Name }\end{array}$ & Event Time & Description & Resources Involved & $\begin{array}{l}\text { Reconfiguration } \\
\text { Approach }\end{array}$ \\
\hline $\begin{array}{l}\text { Go-Ride, } \\
\text { Go-Send }\end{array}$ & $\begin{array}{l}\text { October } \\
2010\end{array}$ & $\begin{array}{l}\text { Start the business } \\
\text { with call center } \\
\text { and } 20 \text { motorbikes }\end{array}$ & $\begin{array}{l}\text { Go-Jek start the business } \\
\text { with limited managerial } \\
\text { team and initiate partnership } \\
\text { with a few drivers }\end{array}$ & $\begin{array}{l}\text { Internal } \\
\text { deployment }\end{array}$ \\
\hline $\begin{array}{l}\text { Go-Ride, } \\
\text { Go-Send }\end{array}$ & $\begin{array}{l}\text { Januray } \\
2015\end{array}$ & $\begin{array}{l}\text { Launches iOS and } \\
\text { Android App }\end{array}$ & $\begin{array}{l}\text { Go-Jek develop own } \\
\text { application for their } \\
\text { activities that enables them } \\
\text { to start a strategic alliance } \\
\text { with scalable crowds ( } 800 \\
\text { drivers) }\end{array}$ & $\begin{array}{l}\text { Internal } \\
\text { deployment and } \\
\text { partnering }\end{array}$ \\
\hline $\begin{array}{l}\text { All } \\
\text { Services }\end{array}$ & March 2015 & $\begin{array}{l}\text { Expands the } \\
\text { operation to Bali } \\
\text { with } 300 \text { drivers }\end{array}$ & $\begin{array}{l}\text { Partnership with } 2200 \\
\text { drivers in Jakarta and } 300 \\
\text { drivers in Bali }\end{array}$ & Partnering \\
\hline Go-Food & April 2015 & $\begin{array}{l}\text { Expands to } \\
\text { Bandung and } \\
\text { launches Go-Food } \\
\text { Services }\end{array}$ & $\begin{array}{l}\text { Adjust the current platform } \\
\text { to accommodate online food } \\
\text { delivery service from any } \\
\text { restaurants }\end{array}$ & Partnering \\
\hline $\begin{array}{l}\text { All } \\
\text { Services }\end{array}$ & June 2015 & $\begin{array}{l}\text { Expands to } \\
\text { Surabaya }\end{array}$ & & Partnering \\
\hline $\begin{array}{l}\text { All } \\
\text { Services }\end{array}$ & $\begin{array}{l}\text { August } \\
2015\end{array}$ & $\begin{array}{l}\text { Expands to } \\
\text { Makassar }\end{array}$ & $\begin{array}{l}\text { Partnering with } 30.000 \\
\text { drivers nationwide }\end{array}$ & Partnering \\
\hline Go-Mart & $\begin{array}{l}\text { September } \\
2015\end{array}$ & Launches Go-Mart & $\begin{array}{l}\text { On-Demand assistant that } \\
\text { partnering with local } \\
\text { physical stores }\end{array}$ & $\begin{array}{l}\text { Internal } \\
\text { deployment and } \\
\text { partnering }\end{array}$ \\
\hline
\end{tabular}




\begin{tabular}{|c|c|c|c|c|}
\hline $\begin{array}{l}\text { Go- } \\
\text { Massage, } \\
\text { Go-Glam, } \\
\text { Go-Clean }\end{array}$ & $\begin{array}{l}\text { October } \\
2015\end{array}$ & $\begin{array}{l}\text { Raises undisclosed } \\
\text { amount of } \\
\text { investment from } \\
\text { Sequoia Capital } \\
\text { and introducing } \\
\text { Go-Massage, Go- } \\
\text { Glam, and Go- } \\
\text { Clean }\end{array}$ & $\begin{array}{l}\text { Adjust the application that } \\
\text { enables for partnering with } \\
\text { crowd with massaging, } \\
\text { cleaning, and beauty service } \\
\text { skills. }\end{array}$ & $\begin{array}{l}\text { Internal } \\
\text { deployment and } \\
\text { partnering }\end{array}$ \\
\hline $\begin{array}{l}\text { All } \\
\text { Services } \\
\text { plus Go- } \\
\text { Tix }\end{array}$ & $\begin{array}{l}\text { December } \\
2015\end{array}$ & $\begin{array}{l}\text { Launches Go-Tix } \\
\text { and expands to } \\
\text { Yogyakarta, } \\
\text { Medan, } \\
\text { Palembang, } \\
\text { Semarang, and } \\
\text { Balikpapan }\end{array}$ & $\begin{array}{l}\text { Adjust their smartphone app } \\
\text { to initiate a partnership with } \\
\text { cinema and event organizer }\end{array}$ & $\begin{array}{l}\text { Internal } \\
\text { deployment and } \\
\text { partnering }\end{array}$ \\
\hline Go-Ride & $\begin{array}{l}\text { January } \\
2016\end{array}$ & $\begin{array}{l}\text { Booking services } \\
\text { for Go-Jek through } \\
\text { LINE (chat } \\
\text { application) }\end{array}$ & $\begin{array}{l}\text { LINE provides Official } \\
\text { Account for Go-Jek that able } \\
\text { to Book the Go-Ride } \\
\text { services }\end{array}$ & Partnering \\
\hline $\begin{array}{l}\text { All } \\
\text { Services }\end{array}$ & $\begin{array}{l}\text { February } \\
2016\end{array}$ & $\begin{array}{l}\text { Acquire software } \\
\text { development } \\
\text { company, C42 } \\
\text { Engineering and } \\
\text { CodeIgnition from } \\
\text { India }\end{array}$ & $\begin{array}{l}\text { Strengthen the internal } \\
\text { development team through } \\
\text { acquihire to enable create } \\
\text { reliable IT infrastructure that } \\
\text { serves current operating } \\
200.000 \text { drivers }\end{array}$ & Acquisition \\
\hline $\begin{array}{l}\text { All } \\
\text { Services } \\
\text { plus Go- } \\
\text { Bluebird }\end{array}$ & May 2016 & $\begin{array}{l}\text { Expands to } \\
\text { Malang, Solo, and } \\
\text { Samarinda as well } \\
\text { as collaboration } \\
\text { with Blue Bird }\end{array}$ & $\begin{array}{l}\text { Start to collaborate for Blue } \\
\text { Bird Taxi-booking services } \\
\text { from Go-Jek platform }\end{array}$ & Partnering \\
\hline Go-Car & April 2016 & Launches Go-Car & $\begin{array}{l}\text { Develop the Uber-like } \\
\text { services within Go-Jek } \\
\text { platform and initiate } \\
\text { strategic alliances with the } \\
\text { car drivers }\end{array}$ & $\begin{array}{l}\text { Internal } \\
\text { deployment and } \\
\text { partnering }\end{array}$ \\
\hline $\begin{array}{l}\text { All } \\
\text { Services }\end{array}$ & June 2016 & $\begin{array}{l}\text { Expands to } \\
\text { Manado }\end{array}$ & & \\
\hline Go-Auto & July 2016 & Launches Go-Auto & $\begin{array}{l}\text { Develop features for call the } \\
\text { auto mechanics and initiate a } \\
\text { partnership with the auto } \\
\text { workshop }\end{array}$ & $\begin{array}{l}\text { Internal } \\
\text { deployment and } \\
\text { partnering }\end{array}$ \\
\hline
\end{tabular}




\begin{tabular}{|c|c|c|c|c|}
\hline $\begin{array}{l}\text { All } \\
\text { Services }\end{array}$ & $\begin{array}{l}\text { August } \\
2016\end{array}$ & $\begin{array}{l}\text { Officially becomes } \\
\text { first unicorn } \\
\text { startup from } \\
\text { Indonesia. }\end{array}$ & $\begin{array}{l}\text { Received new funding more } \\
\text { than } \$ 550 \text { million from } \\
\text { several institutions including } \\
\text { KKT, and Co., Warburg } \\
\text { Pincus LLC., Farallon } \\
\text { Capital Management LLC, } \\
\text { and Capital Group Cos as a } \\
\text { result of Go-Jek } \\
\text { performance with more than } \\
20 \text { million times apps } \\
\text { download }\end{array}$ & \\
\hline $\begin{array}{l}\text { All } \\
\text { services }\end{array}$ & May 2017 & $\begin{array}{l}\text { Go-Jek India } \\
\text { Launches }\end{array}$ & $\begin{array}{l}\text { The acquihired teams from } \\
\text { several Indian software } \\
\text { development firms were } \\
\text { relocated in the new } \\
\text { organizational structure as } \\
\text { engineering firm called Go- } \\
\text { Jek India }\end{array}$ & Acquisition \\
\hline
\end{tabular}

In a strategic alliance perspective in the platform context, network effects play prominent role for Go-Jek's competitive advantage. The platform envelopment strategy discussed above strengthens Go-Jek competitiveness by using the envelopment target platform's network effects to enter new markets. For example, target platforms such as Food Panda, an online food delivery service, was forced to close its business when GoJek, with their Go-Food service, acquired a significant number of Food Panda's users (Freischlad, 2016). The bundling services between frequent use P2P online transportation and food delivery service lowers the multi-homing cost and leaves no chance for Food Panda to fight back. The network effects of Food Panda that previously created barriers for its competitors, turned into a channel that enabled envelopment attacker platforms such as Go-Food to acquire its users, as most of Food Panda users were also users of Go-Jek's P2P online transportation services.

From the perspective of the Go-Jek driver, or of any other Go-Jek microentrepreneur, the flexibility of being a supplier on the platform became one of the most influencing reason to join the platform (Primaldhi, 2017). The strategic alliance scheme offered by Go-Jek has low interdependence with the micro-entrepreneurs such as allowing very flexible working times and little control over operating activities as long as customers do not give negative feedback. The income and bonuses that the microentrepreneurs can achieve are based almost solely on their effort. This setting is very suitable for micro-entrepreneurs with high opportunistic behavior, especially in terms of economic and working time benefits. As a result, many employees from other institutions and even students join the Go-Jek platform as part-time workers. However, unlike other players in informal sectors, most of the micro-entrepreneurs in Go-Jek's platform have decent IT capabilities to operate the mobile application. This situation also enables Go-Jek to quickly introduce innovation within their platform that can be delivered by the same supplier side user segment such as Go-Pay, Go-Food, Go-Tix and Go-Mart.

Even though the strategic alliance scheme seems promising for the platform suppliers, since Go-Jek acquires the alliance partners from the crowd as well as 
strangers in the market, the complexity of the alliances can be pretty challenging. For example, a new arrangement that relates to economic benefits such as tariff adjustment and bonuses can make Go-Jek drivers feel unrest (Antony, 2016). Nevertheless, those strangers also bring positive impact to the platform in term of service innovation and word-of-mouth to acquire more micro-entrepreneurs as supplier side partners. Furthermore, Go-Jek itself receives beneficial organizational learning from the supplier-customer interactions that can be monitored real-time to understand the routine in the field and what solution does the customer really want.

Besides conducting strategic alliances with crowd micro-entrepreneurs, in the past year Go-Jek also initiated strategic alliances with established institutions to innovate its business model. For instance, the company established partnerships with Bank BCA, Mandiri, and BNI to provide financial technology services for digital payment, implemented in Go-Pay (Sugianto, 2016). In addition, Go-Jek initiated strategic alliances by providing $\$ 13$ million Series A investments along with Clermont Group, blibli.com and NSI Ventures for another MSP firm, HaloDoc, to strengthen their Go-Med service within the ecosystem in e-commerce health sector. However, in order to keep up their high growth, Go-Jek does not only rely on the strategic alliances with external parties, but also on strengthening their internal resources by acquihiring several software development firms from India such as C42 Engineering, CodeIgnition, Pianta, and LeftShift Technologies. Furthermore, in order to get e-money license for their Go-Pay service, Go-jek also acquired a financial technology firm, PonselPay.

In general, Go-Jek's strategic alliance implementation discussed in this section provides significant contribution for its high growth over the past three years. The company started with initiating a strategic alliance with the micro-entrepreneurs from the crowd. The significant growth derived from this strategy in term of equity growth and market value growth allowed them to strengthen their internal resources by acquiring other institutions supporting their business. Lastly, Go-Jek conducted strategic alliance with other firms that allowed them to strengthen their business within e-commerce ecosystem.

\section{Present and future implication for service industry}

Go-Jek is a typical high-growth firm able to change the existing industrial landscape. It is not only disrupting other MSP firms with platform envelopment as discussed in previous section, but also disrupting existing established firms. Go-Jek's strategic alliance with massive crowd-based resources drives a platform disruption that is very scalable. Along with other sharing economy firms such as Uber and Grab, the existence of Go-Jek has been able to reduce the net profit for Blue Bird, the largest Indonesian taxi operator firm, from USD 47 million in the $3^{\text {rd }}$ quarter of 2015 to USD 27.1 billion in the $3^{\text {rd }}$ quarter of 2016 (Blue Bird Group, 2016). Another taxi operator company, Express, suffered USD 6.1 million loss in the $3^{\text {rd }}$ quarter of 2016 (Kasali, 2016). The lower trip fare (almost 40\%) even without promotional discount, availability of vehicles, as well as ease of access from smartphone of Go-Jek and other sharing economy firms are the main factors of this phenomenon. Interestingly, this situation led to another strategic alliance between a threatened incumbent firm, Blue-Bird, and the disruptor, Go-Jek, resulting in a taxi-booking app service called Go-Bluebird within Go-Jek platform (Fauzi, 2017). 
The significant growth of Go-Jek in such a short time cannot be separated from the role of top-tier venture capital and private equity institution such as Sequoia Capital, Tencent Holdings, Northstar Group, KKR, and Co., and other financial institutions that provided a total equity funding of $\$ 1.75$ billion in three investment rounds (Crunchbase, 2017). Since Go-Jek's offers of multi-services stated by their slogan "An Ojek for Every Need", other service industries that are close to Go-Jek's services may also be affected the implication in the future, especially if Go-Jek utilizes its enormous financial resources. The services previously offered by established institutions such as inner-city logistic delivery services can now be performed by any micro-entrepreneurs who own a motorbike by using the Go-Jek platform. In addition, since the past year, Go-Jek has conducted strategic alliances with big e-commerce players such as Tokopedia and Bukalapak for same-day delivery services with much lower price than conventional logistic firms (Arifin, 2017). Furthermore, as of mid-2017, Go-Jek has broadened its strategic alliances in this sector to serve online shops that operate through Instagram (Go-jek.com, 2017).

For the logistic firms, it is difficult to replicate Go-Jek business model since their platforms are not designed based on acquiring the highly scalable micro-entrepreneurs for conducting main business processes. Logistic firms mostly rely on full-time employees to carry out these activities. As a result of this disruption, some logistics firms have raised this issue to the government in the attempt of banning Go-Jek and other sharing economy-based logistic services for logistic license issue (Primadhyta, 2016). All in all, in the future, services from other sectors may also be disrupted by GoJek if these services can be carried out by micro-entrepreneurs with comparable quality of services such as for the transportation and logistics services.

\section{B. Tokopedia}

Similar to Go-Jek, Tokopedia is also considered a unicorn startup by several media according to their performance and funds secured, even though Tokopedia itself never announced it publicly (Agung, 2017). In the beginning, Tokopedia operated in Indonesia Tokopedia offered a sophisticated solution to the fraud problems of electronic commerce performed on Interned forums. In this kind of e-commerce, buyers used to meet sellers on forums, agree with them the prices of the goods they wanted to purchase, and pay with a bank transfer directly to the seller's account. In order to minimize the fraud, some Internet forum users created joint bank accounts that could be used as a payment method by buyers and sellers. During the transaction, buyers would first send the payment to the joint bank account. After the buyers had received the goods without any problem, sellers were able to retrieve the payment from the joint bank account into their personal or business bank account. In 2009, Tokopedia combined this joint bank account features as an escrow service managed internally with $\mathrm{C} 2 \mathrm{C}$ or marketplace platform and provided a trusted and safe solution for both buyers and sellers to conduct online shopping activities. From this point, along with their direct competitor Bukalapak, Tokopedia became the main platform to bring microentrepreneurs online.

Tokopedia growth strategy is quite different from Go-Jek's broad diversification approach. Tokopedia choose to focus its growth as online shopping platform despite the increasing variety of products and sellers. Similar to other MSP firms, Tokopedia relies 
on the micro-entrepreneurs at the supplier side as their main business activity. After receiving Series D and Series E investments for a total of more than $\$ 247$ million in 2013 and 2014 from top-tier private equity and venture capital such as Softbank Ventures Korea, Softbank Telecom Corp, Sequoia Capital, East Ventures, and CyberAgent Ventures, Tokopedia secured more strategic alliances with the microentrepreneurs to make sure to have the most complete products and sellers compared to any other marketplace platform (Anestia, 2015). Furthermore, in order to manage its growth, Tokopedia initiated many strategic alliances with institutions relevant to its core business of marketplace platform. The chronological order of Tokopedia's growth strategy is presented in Table 4.

Table 4

Tokopedia selected platform strategies

\begin{tabular}{|c|c|c|c|c|}
\hline $\begin{array}{l}\text { Product / Service } \\
\text { Name }\end{array}$ & $\begin{array}{l}\text { Event } \\
\text { Time }\end{array}$ & Description & Resources Involved & $\begin{array}{l}\text { Reconfiguration } \\
\text { Approach }\end{array}$ \\
\hline Tokopedia.com & $\begin{array}{l}\text { August } \\
2009\end{array}$ & $\begin{array}{l}\text { Tokopedia } \\
\text { launches its } \\
\text { services } \\
\text { under PT. } \\
\text { Tokopedia } \\
\text { for their legal } \\
\text { entity }\end{array}$ & $\begin{array}{l}\text { Start the online } \\
\text { marketplace business } \\
\text { with escrow services }\end{array}$ & $\begin{array}{l}\text { Internal } \\
\text { Development }\end{array}$ \\
\hline Tokopedia.com & $\begin{array}{l}\text { October } \\
2014\end{array}$ & $\begin{array}{l}\text { Raises } \$ 100 \\
\text { million } \\
\text { investment } \\
\text { from } \\
\text { Softbank } \\
\text { Internet and } \\
\text { Media as } \\
\text { well as } \\
\text { Sequoia } \\
\text { Capital }\end{array}$ & $\begin{array}{l}\text { Knowledge transfers } \\
\text { from leading venture } \\
\text { capital }\end{array}$ & \\
\hline $\begin{array}{l}\text { Ciptakan } \\
\text { Peluangmu (Create } \\
\text { your Opportunity) } \\
\text { Campaign }\end{array}$ & $\begin{array}{l}\text { August } \\
2015\end{array}$ & $\begin{array}{l}\text { Massive } \\
\text { campaign for } \\
\text { acquiring } \\
\text { Tokopedia } \\
\text { sellers }\end{array}$ & $\begin{array}{l}\text { Strategic alliance with } \\
\text { the micro-entrepreneurs } \\
\text { to tell their success } \\
\text { story within Tokopedia } \\
\text { platform and ask them } \\
\text { to bring their relatives } \\
\text { to the platform }\end{array}$ & Partnering \\
\hline Tokopedia.com & $\begin{array}{l}\text { September } \\
2015\end{array}$ & $\begin{array}{l}\text { Launches } \\
\text { Qurban } \\
\text { services for } \\
\text { Moslem }\end{array}$ & $\begin{array}{l}\text { Initiate a partnership } \\
\text { with Dompet Dhuafa } \\
\text { and Rumah Zakat for } \\
\text { providing Qurban } \\
\text { services for Moslem }\end{array}$ & Partnering \\
\hline
\end{tabular}




\begin{tabular}{|c|c|c|c|c|}
\hline City.tokopedia.com & June 2016 & $\begin{array}{l}\text { Launches } \\
\text { online } \\
\text { marketplace } \\
\text { platform for } \\
\text { SMEs in } \\
\text { specific cities }\end{array}$ & $\begin{array}{l}\text { Partnering with } \\
\text { municipal government } \\
\text { to make local SMEs go } \\
\text { online }\end{array}$ & $\begin{array}{l}\text { Internal } \\
\text { development } \\
\text { and partnering }\end{array}$ \\
\hline Ninja Express & $\begin{array}{l}\text { October } \\
2016\end{array}$ & $\begin{array}{l}\text { Introduce } \\
\text { Ninja } \\
\text { Express for } \\
\text { same-day } \\
\text { delivery } \\
\text { services }\end{array}$ & $\begin{array}{l}\text { Initiate strategic } \\
\text { alliance with P2P } \\
\text { online transportation } \\
\text { for logistic services }\end{array}$ & Partnering \\
\hline Century Healthcare & $\begin{array}{l}\text { November } \\
2016\end{array}$ & $\begin{array}{l}\text { Introduce } \\
\text { official store } \\
\text { for } \\
\text { pharmacy, } \\
\text { Century } \\
\text { Healthcare }\end{array}$ & $\begin{array}{l}\text { Initiate a strategic } \\
\text { alliance with Apotek } \\
\text { Century for providing } \\
\text { health services for } \\
\text { Tokopedia users }\end{array}$ & Partnering \\
\hline Oppo Smartphone & $\begin{array}{l}\text { November } \\
2016\end{array}$ & $\begin{array}{l}\text { Introduce } \\
\text { opportunity } \\
\text { Smartphone } \\
\text { official store }\end{array}$ & $\begin{array}{l}\text { Initiate a partnership } \\
\text { with opportunity for } \\
\text { strengthening the } \\
\text { mobile devices } \\
\text { marketing channel } \\
\text { supported with same- } \\
\text { day delivery services }\end{array}$ & Partnering \\
\hline $\begin{array}{l}\text { Credit Card } \\
\text { Application }\end{array}$ & $\begin{array}{l}\text { December } \\
2016\end{array}$ & $\begin{array}{l}\text { Launches } \\
\text { credit card } \\
\text { application } \\
\text { services }\end{array}$ & $\begin{array}{l}\text { Partnership with } \\
\text { Citibank, HSBC, and } \\
\text { Standard Chartered to } \\
\text { offer their credit card } \\
\text { for Tokopedia users }\end{array}$ & $\begin{array}{l}\text { Internal } \\
\text { development } \\
\text { and partnering }\end{array}$ \\
\hline $\begin{array}{l}\text { Transaction with } \\
\text { gift card }\end{array}$ & $\begin{array}{l}\text { February } \\
2017\end{array}$ & $\begin{array}{l}\text { Launches } \\
\text { payment with } \\
\text { gift card }\end{array}$ & $\begin{array}{l}\text { Partnership with } \\
\text { TaDa!, Hadiah.me and } \\
\text { excite shop to provide } \\
\text { gift card code for } \\
\text { transaction within } \\
\text { Tokopedia platform }\end{array}$ & $\begin{array}{l}\text { Internal } \\
\text { development } \\
\text { and partnering }\end{array}$ \\
\hline TokoCash & $\begin{array}{l}\text { March } \\
2017\end{array}$ & $\begin{array}{l}\text { Launches } \\
\text { financial } \\
\text { technology } \\
\text { platform for } \\
\text { payment } \\
\text { services }\end{array}$ & $\begin{array}{l}\text { Develop fintech } \\
\text { platform to pay } \\
\text { Tokopedia billing and } \\
\text { also other platform } \\
\text { billing }\end{array}$ & $\begin{array}{l}\text { Internal } \\
\text { development }\end{array}$ \\
\hline LINE & May 2017 & $\begin{array}{l}\text { Introduce } \\
\text { new promo } \\
\text { channel with } \\
\text { LINE (chat } \\
\text { application) }\end{array}$ & $\begin{array}{l}\text { Initiate a strategic } \\
\text { alliance with LINE to } \\
\text { promote new } \\
\text { Tokopedia offering for } \\
\text { LINE users by utilizing } \\
\text { LINE Official Account }\end{array}$ & Partnering \\
\hline
\end{tabular}


E-commerce industry is considered a winner-takes-all (WTA) market with a high concentration level and few survivors. Despite the growing number of e-commerce players of the recent years, only few have been able to have performances close to Tokopedia's. Furthermore, the network effects became stronger when Tokopedia initiated other strategic alliances with anchor sellers such as PT KAI (state-owned enterprise for railway transportation), firms with branded product to be placed on Tokopedia official store, and also well-known digital products providers that offer evoucher and subscription services (KOMPAS.com, 2017). In addition, Tokopedia joined forces with municipal governments of major cities in Indonesia such as Jakarta, Bandung, and Semarang to make their SMEs go online as well as support the government development program for SMEs (Yasa, 2017). The loyal customers from those sellers are attracted to become Tokopedia users. In this matter, direct network effect between the brands' customers also created word-of-mouth to attract other customers who were not platform users.

In order to grow the platform's users, besides initiating strategic alliances with anchor sellers, Tokopedia conducted this strategy with established institutions that brought more value for the customers of the platform. They tried to have resonance with the users' life as close as possible. When this will be accomplished, Tokopedia platform will be able solve more daily life problems for its users. For example, when customers need to receive the goods that they buy as soon as possible, they will initiate strategic alliances with two leading P2P online transportation service providers, Go-Jek and Grab, to offer same-day delivery services at a reasonable price (Arifin, 2017). In addition, Tokopedia offers important billing payment services or pre-paid vouchers for utilities such as electricity, telecommunication, water, Internet data, credit installment, paid-TV, health insurance and so on. In doing so, they established strategic alliances with each service provider (KOMPAS.com, 2017). Recently, Tokopedia created a strategic alliance with a messenger app, LINE, used by many young people in Indonesia to help the MSP firm promote new offerings right on the customers' palm (Tokopedia Blog, 2017a).

Most digital MSP firms interact with financial related activities within their transactions. Therefore, they are close to opportunities that can be explored. Tokopedia exploits this opportunity by providing capital-lending services to the microentrepreneurs who utilize the platform (Meodia, 2016). By doing so, Tokopedia is able to create a virtuous cycle where the micro-entrepreneurs join the platform at the supplier side, start the business with that capital, earn income, payback the capital with some interest, lend more capital, grow their business and attracts more customers to the platform as a result. In the beginning of this program, Tokopedia initiated partnerships with P2P lending platforms as well as banks to provide the funds (Hanum, 2016). In the further development, Tokopedia is not only providing lending services for the microentrepreneurs, but also for the customers as consumption loan by utilizing high user traffic (Tokopedia.com, 2017a). Another strategic alliance initiative is TravelersBox, able to convert a small amount of foreign currency from tourist into Tokopedia electronic money, strengthening Tokopedia position as emerging financial technology firm (Tokopedia Blog, 2017b).

Basically, Tokopedia enhances or even develops micro-entrepreneurs' IT capabilities that did not previously exist. This is particularly relevant, as the success of strategic alliances with informal crowds is highly determined by IT capabilities for the 
exchange of knowledge as well as the implementation of new solutions. Therefore, various online community development events with relevant topics such as SEO optimization and logistics for e-commerce are held by Tokopedia to support their sellers' IT capabilities (Suffia, 2017). Furthermore, the micro-entrepreneurs have a significant role for Tokopedia's freemium business model. When the microentrepreneurs have a high participation level in seller community forums, they are more likely to use Tokopedia premium features such as Gold Merchant, which includes advertising within platform, gold merchant badge, cashback promo for customer side, store statistics, and so on (Tokopedia.com, 2017b). Overall, as the main platform for micro-entrepreneurs in retail industry, Tokopedia has successfully created an ecosystem through strategic alliance with multiple parties, mostly from informal crowd entities and supported by formal institution entities.

\section{Present and future implication for the retail industry}

As the pioneer in the Indonesian online marketplace, Tokopedia disrupted incumbents for incumbent with traditional business models. Even though the disruption effect is not as rapid as Go-Jek to taxi industry, the disruption effect starts to threat shopping malls that rely on micro-entrepreneurs as their tenant. In the past years, there has been a significant decrease of kiosk space demand for sales in shopping malls (Sukmana, 2017). The growth of e-commerce traffic, especially on online marketplaces, drives micro-entrepreneurs to shift to online marketplaces to carry out their activities. Furthermore, doing micro Furthermore, by doing micro business online, many of them only rent only rent a small space of kiosk in the shopping mall for creating a physical evidence for their customer as well as to proof that their business is not a fraud online business.

In a disruptive innovation perspective (Christensen, 1997), Tokopedia starts to threat the incumbent, shopping malls, by acquiring the foothold customers from supplier side, the low-capital micro-entrepreneurs, that cannot afford to purchase a kiosk space in the shopping mall. Generally, this type of micro-entrepreneurs sell infamous brands with a cheap price or segmented hobbyist products. As a result, in the beginning Tokopedia customers are online marketplace users who search for these kinds of products. However, when the micro-entrepreneurs get more income and more support facilities such as capital lending services, they are able to grow their business by offering more famous branded products with better profit margins. At this point, Tokopedia starts to attract mainstream customer from supplier side, the decent microentrepreneurs. As a result, the well-known brands are traded at Tokopedia by these micro-entrepreneurs. Moreover, when Tokopedia initiates strategic alliances with wellknown brands by providing official store at Tokopedia platform, they also attracted mainstream customer from another side, the traditional shopping malls customers.

In the long run, the growth of online marketplace supported with rapid adoption and technological advancement of information technology has the potential to shift the presence of physical marketplaces such as shopping malls. However, from a customer perspective, physical store is still necessary for enhancing the trust toward the store as well as giving the physical experience before buying for experience goods type. For this reason, the leading fashion e-commerce such as Zalora and Berrybenka opened their physical store at shopping malls (Freischlad, 2017; Riska, 2014). Nonetheless, the 
emerging online marketplace growth showed by Tokopedia needs to receive full attention from traditional physical store players.

\section{IMPLICATIONS FOR THEORY AND ANALYSIS}

The two cases of strategic alliances conducted by two high-growth MSP presented above show that beside internal resources, external resources have a prominent role in determining the growth of MSP firms. Resource-Based theory explains why the firms perform differently by the premise of heterogeneity of resources (Barney, 1991; Wernerfelt, 1984). The entrepreneurship literatures have examined the resource-linking logic that explains about the source of the survival and growth of the new firms comes from their partner resources (Baum et al., 2000; Schoonhoven, and Eisenhardt, 1996). This is consistent with the growth of resource-dependence theory that emphasizes the opportunity of having complementary resources (Pfeffer and Salancik, 1978). The external resources and internal resources play different roles for the firm performance (Capron and Mitchell, 2009). The internal resources take the role of capability development and value capture (Helfat, 1994). On the other hand, external resources take the role of exploration and capability extension (Karim and Mitchell, 2000). The resource reconfiguration of Go-Jek and Tokopedia is presented in Table 3 and Table 4 by adapting Rindova et al.'s (2016) work.

In the platform-mediated networks context, the valuable resource is not only internal resource that is fully controlled by the firm but also external resources such as platform complementors or supplier side including their indirect network effect (Eisenmann et al., 2011). Hence, the dynamic capabilities for MSP firms need to include both internal and external capabilities to achieve longer competitive advantage. The process to tap the complementor innovation and the supplier is considered as one of the sensing element for market and technological opportunities (Teece, 2007). In this matter, the economic scale and scope depend on the contractual access (Teece, 1980). Therefore, the enterprise boundary has been softened in this setting.

The dynamic capabilities of the firm do not only lay on the internal organization but also lay on the inter-organizational relationship. The latter one might be more relevant when firms adopt open innovation (Chesbrough, 2003). In this setting, the external partners can range from individuals to collaborate with institutions as long as they contribute to the platform ecosystem innovation. Hence, in the seizing stage, selecting enterprise boundaries to manage complementors and control the platform is one of the most prominent strategic decision skills or execution. The activities range from calibrating asset specificity, controlling bottleneck assets, assessing appropriability, recognizing, managing, and capturing co-specialization economies. The co-specialization itself becomes the main capability in combination and reconfiguration stage for the platform setting.

The strategic alliances within MSP firms also have implications for the disruptive innovation theory. The growth of scope and scale showed by Go-Jek and Tokopedia enabled the MSP firms to acquire mainstream customer by using foothold customers as a stepping stone. In disruptive innovation theory, the disruptors start to threat the incumbents by penetrating the foothold market (Schmidt, and Druehl, 2008; Christensen, 1997). The foothold market itself can be either a low-end market that serves overshoot customer segments or a new-market segment that serves different 
value network for the incumbent. Integration capabilities strengthen the core competence by integrating internal resources with external resources that are categorized as platform complementors (Rindova et al., 2012). This integration can improve the performance attribute of the inferior platform services to more acceptable levels over time. When the time comes, the incumbents will have difficulties to counter the disruptors since industry platform disruption process includes a much broader supply side compared to the traditional incumbents that usually only includes an internal platform. Therefore, low-end disruptive innovation trajectories may happen with this process.

\section{CONCLUSIONS AND FURTHER RESEARCH}

The MSP strategies as well as the two empirical cases discussed in this article cover business models, network effects, platform envelopment, and growth strategies. Previous strategic alliances studies include strategic alliances with suppliers and customers, effect of IT capabilities in strategic alliances, alliances portfolio creation and firm innovativeness, strategic alliances in small business perspective, and franchise. Based on the literatures discussed, there are several gaps remain to be explored such as the effects of business model type to strategic alliances performance, the development of MSP user capability through strategic alliance, and also the maintenance of alliances for MSP users to embrace the platform competition.

From the above discussion, we may also conclude that to have a successful strategic alliance with platform users in MSP context, the MSP firm should pay attention to IT capabilities of platform members, the interdependence between MSP firms and their members, platform members' social network ties, and also generalized "franchising" systems that can be used by the platform members. The result of a successful implementation of strategic alliances within MSP firms' context has the potential to disrupt the incumbent firms with traditional business models.

\section{REFERENCES}

Agung, B., 2017, "Induk Usaha JD.id Gelontorkan Jutaan Dolar ke Tokopedia?" [online] CNN Indonesia. Available at: https://www.cnnindonesia.com/ teknologi/20170503114153-185-211861/induk-usaha-jdid-gelontorkan-jutaandolar-ke-tokopedia/ [Accessed 17 Nov. 2017].

Alstyne, V.M.W., G.G. Parker, and S.P. Choudary, 2016, "Pipelines, Platforms, and the New Rules of Strategy." Harvard Business Review, 94(4), 54-62.

Anestia, C., 2015, "Dukung UKM, Tokopedia Gelar Kampanye `Ciptakan Peluangmu." [online] liputan6.com. Available at: http://tekno.liputan6.com/read/2295560/ dukung-ukm-tokopedia-gelar-kampanye-ciptakan-peluangmu [Accessed 17 Nov. 2017].

Antony, N., 2016, "Dari Sistem hingga Tarif, Begini 7 Tuntutan Driver Go-Jek ke Perusahaan." [online] detiknews. Available at: https://news.detik.com/berita/d3311971/dari-sistem-hingga-tarif-begini-7-tuntutan-driver-go-jek-ke-perusahaan [Accessed 15 Nov. 2017].

Arifin, C., 2017, "Kiriman Paket Go-Send Sekarang Bisa Diterima di Hari yang Sama." [online] Tribunnews.com. Available at: http://www.tribunnews.com/techno/2017/ 
01/18/kiriman-go-send-sekarang-bisa-diterima-di-hari-yang-sama [Accessed 15 Nov. 2017].

Barney, J. 1991, "Firm Resources and Sustained Competitive Advantage." Journal of Management, 17(1), 99-120.

Barney, J.B., 1986, "Strategic Factor Markets: Expectations, Luck, and Business Strategy." Management Science, 32(10), 1231-1241.

Baum, J.A., T. Calabrese, and B.S. Silverman, 2000, "Don't Go It Alone: Alliance Network Composition and Startups' Performance in Canadian Biotechnology." Strategic Management Journal, 267-294.

Bernoff, J., and C. Li, 2008, "Harnessing the Power of the Oh-so-social Web", MIT Sloan Management review, 49(3), 36-42.

Blue Bird Group, 2016, “Blue Bird Group Annual Report 2016.” Retrieved from: http://www.bluebirdgroup.com/wp-content/uploads/2015/10/AR-2016-PT-BlueBird-e-reporting1.pdf

Caillaud, B., and B. Jullien, 2003, "Chicken, and Egg: Competition among Intermediation Service Providers." RAND Journal of Economics, 309-328.

Campbell-Kelly, M., D. Garcia-Swartz, R. Lam, and Y. Yang, 2015, "Economic and Business Perspectives on Smartphones as Multi-sided Platforms." Telecommunications Policy, 39(8), 717-734.

Capron, L., and W. Mitchell, 2009. "Selection Capability: How Capability Gaps and Internal Social Frictions Affect Internal and External Strategic Renewal." Organization Science, 20(2), 294-312.

Crunchbase, 2017, "GO-JEK." [online] Available at: https://www.crunchbase.com/ organization/go-jek [Accessed 17 Nov. 2017].

Chesbrough, H., 2003, "The Logic of Open Innovation: Managing Intellectual Property." California Management Review, 45(3), 33-58.

Christensen, C.M., 1997, “The Innovator's Dilemma: When New Technologies Cause Great Firms to Fail." Harvard Business Press: Boston, MA.

Combs, J.G., D.J. Ketchen, C.L. Shook, and J.C. Short, 2011, "Antecedents and Consequences of Franchising: Past Accomplishments and Future Challenges." Journal of Management, 37(1), 99-126.

DeSarbo, W.S., A.D.C. Benedetto, and I. Sinha, 2005, "Revisiting the Miles and Snow Strategic Framework: Uncovering Interrelationships between Strategic types, Capabilities, Environmental Uncertainty, and Firm Performance." Strategic Management Journal, 26(1), 47-74.

Dierickx, I., and K. Cool, 1989, “Asset Stock Accumulation and Sustainability of Competitive Advantage." Management Science, 35(12), 1504-1511.

Eisenmann, T., G. Parker, and V.M.W. Alstyne, 2011, "Platform Envelopment." Strat. Mgmt.J., 32, 1270-1285.

Eisenmann, T.R., 2006, 'Internet Companies' Growth Strategies: Determinants of Investment Intensity and Long-term Performance." Strategic Management Journal, 27(12), 1183-1204.

Eisenmann, T., G. Parker, and V.M.W. Alstyne, 2006, "Strategies for Two-sided Markets." Harvard Business Review, 84(10), 92-101.

Evans, D.S., 2003, "Some Empirical Aspects of Multi-sided Platform Industries." Review of Network Economics, 2(3), 191-209. 
Fauzi, A., 2017, "Taksi BlueBird Gandeng GO-JEK luncurkan GO-BLUEBIRD." [online] KOMPAS.com. Available at: http://bisniskeuangan.kompas.com/read/ 2017/03/30/125139626/taksi.bluebird.gandeng.go-jek.luncurkan.go-bluebird [Accessed 15 Nov. 2017].

Freischlad, N., 2017, "Berrybenka CEO on Why He's Opening Offline Stores.” [online] Techinasia.com. Available at: https://www.techinasia.com/why-berrybenka-opensoffline-stores [Accessed 17 Nov. 2017].

Freischlad, N., 2016, "Why Foodpanda and OpenRice Are Losing Their Appetite for Indonesia." [online] Techinasia.com. Available at: https://www.techinasia.com/ foodpanda-openrice-losing-appetite-indonesia [Accessed 15 Nov. 2017].

Gawer, A., and M.A. Cusumano, 2008, "How Companies Become Platform Leaders." MIT Sloan Management Review, 49(2), 28-35.

Go-jek.com., 2017, "GO-JEK Indonesia | Laris Manis Bersama GO-JEK.” [online] Available at: https://www.go-jek.com/larismanis/ [Accessed 17 Nov. 2017].

Golonka, M., 2015, "Proactive Cooperation with Strangers: Enhancing Complexity of the ICT Firms' Alliance Portfolio and Their Innovativeness." European Management Journal, 33(3), 168-178.

Hagiu, A., and J. Wright, 2015, "Multi-sided Platforms." International Journal of Industrial Organization, 43, 162-174.

Hagiu, A., and J. Wright, 2014, "Marketplace or Reseller?" Management Science, 61(1), 184-203.

Hagiu, A. and J. Wright (2013) "Do You Really Want to Be an eBay?" Harvard Business Review, 91 (3), 102-108.

Hanum, A., 2016, "Tokopedia Berikan Pinjaman Modal Para Merchant.” [online] Bisnis.com. Available at: http://entrepreneur.bisnis.com/read/20160614/263/ 557356/tokopedia-berikan-pinjaman-modal-para-merchant [Accessed 17 Nov. 2017].

Heber, A., 2017, "An Indonesian on-demand motorcycle taxi startup is trying to hire 16,000 drivers in four days." [online] Business Insider Australia. Available at: https://www.businessinsider.com.au/an-indonesian-on-demand-motorcycle-taxistartup-is-trying-to-hire-16000-drivers-in-four-days-2015-8 [Accessed 15 Nov. 2017].

Helfat, C. E., 1994, "Firm-specificity in Corporate Applied R\&D." Organization Science, 5(2), 173-184.

Hutabarat, L., 2015, "Begini Hitung-hitungan Pendapatan Driver Gojek." [online] News.metrotvnews.com. Available at: http://news.metrotvnews.com/read/ 2015/06/30/141851/begini-hitung-hitungan-pendapatan-driver-gojek [Accessed 15 Nov. 2017].

Kasali, R., 2016, "OPINI: Ekonomi Indonesia Hadapi Lawan-Lawan Tak Kelihatan.” [online] liputan6.com. Available at: http://bisnis.liputan6.com/read/2688829/opiniekonomi-indonesia-hadapi-lawan-lawan-tak-kelihatan [Accessed 17 Nov. 2017].

Karim, S., and W. Mitchell, 2000, "Path-dependent and Path-breaking Change: Reconfiguring Business Resources Following Acquisitions in the US Medical Sector." 1978-1995. Strategic Management Journal, 21(10-11), 1061-1081.

KOMPAS.com. 2017, "Bayar Pajak Bumi dan Bangunan Pun Sekarang Bisa Dimulai dari Tokopedia." [online] Available at: http://biz.kompas.com/read/2017/ 
10/31/104432428/bayar-pajak-bumi-dan-bangunan-pun-sekarang-bisa-dimulaidari-tokopedia [Accessed 17 Nov. 2017].

Krazit, T., 2008, "Apple Unveils iPhone 2, both the Phone and the Business." CNET News. June 9.

Liebowitz, S., and S. Margolis, 2001, "Network Effects and the Microsoft Case." Dynamic Competition and Public Policy: Technology, Innovation, and Antitrust Issues. Cambridge: Cambridge University Press, 160-192.

Lioukas, C. S., J. J. Reuer, and M. Zollo, 2016, "Effects of Information Technology Capabilities on Strategic Alliances: Implications for the Resource-based View." Journal of Management Studies, 53(2), 161-183.

Meodia, A., 2016, "Tokopedia bantu pebisnis online lewat modal pinjaman." [online] Antara News. Available at: https://www.antaranews.com/berita/567108/tokopediabantu-pebisnis-online-lewat-modal-pinjaman [Accessed 17 Nov. 2017].

Moore, B., 2017, “A recent history of the Indonesian e-commerce industry: an insider's account." Digital Indonesia: Connectivity and Divergence. Singapore: ISEAS Yusof Ishak Institute, 256-274.

Mossberg, W., 2010, "Learning About Everything Under The 'Cloud'." [online] WSJ. Available at: https://www.wsj.com/articles/SB10001424052748703961104575226 194192477512 [Accessed 17 Nov. 2017].

Oestreicher-Singer, G., and L. Zalmanson, 2013, "Content or Community? A Digital Business Strategy for Content Providers in the Social Age." MIS Quarterly, 37(2), 591-616.

Parker, G.G., and V.M.W. Alstyne, 2005, “Two-sided Network Effects: A Theory of Information Product Design." Management Science, 51(10), 1494-1504.

Peteraf, M. A., and M. E. Bergen, 2003, "Scanning Dynamic Competitive Landscapes: A Market-based and Resource-based Framework." Strategic Management Journal, 24(10), 1027-1041.

Pfeffer, J., and R. Gerald, Salancik, 1978, “The External Control of Organizations: A Resource Dependence Perspective." New York: Harper and Row Publishers

Preece, J., and B. Shneiderman, 2009, "The Reader-to-leader Framework: Motivating Technology-mediated Social Participation." AIS Transactions on HumanComputer Interaction, 1(1), 13-32.

Primadhyta, S., 2016, "Perusahaan Logistik Desak Pemerintah Tertibkan Gojek dan Grab." [online] CNN Indonesia. Available at: https://www.cnnindonesia.com/ ekonomi/20160321153228-92-118804/perusahaan-logistik-desak-pemerintahtertibkan-gojek-dan-grab/ [Accessed 17 Nov. 2017].

Primaldhi, A. (2017). "Hasil Riset Manfaat Sosial Aplikasi on Demand: Studi Kasus GO-JEK Indonesia." Jakarta: Puskakom UI.

Raharso, A.P., and S.K. Sia, 2017, "Go-Jek in Indonesia: Seizing Digital Opportunities at the Bottom of the Pyramid." HBS No. NTU131. Boston, MA: Harvard Business School Publishing, 1-18.

Rindova, V.P., L.L. Martins, L.L., A. Yeow, 2016, "The hare and the fast tortoise: Dynamic resource reconfiguration and the pursuit of new growth opportunities by Yahoo and Google (1995-2007)." Folta TB, Helfat CE, Karim S, eds. Advances in Strategic Management, Resource Redeployment and Corporate Strategy, Vol. 35. Bingley: Emerald Group Publishing, 253-284. 
Riska, M., 2014, “Zalora buka gerai fisik di Kota Kasablanka.” [online] kontan.co.id. Available at: http://industri.kontan.co.id/news/zalora-buka-gerai-fisik-di-kotakasablanka [Accessed 17 Nov. 2017].

Rochet, J.C., and J. Tirole, 2003, "Platform Competition in Two-sided Markets.” Journal of the European Economic Association, 1(4), 990-1029.

Santoso, A. S., and Erdaka, A., 2015, "Customer Loyalty in Collaborative Consumption Model: Empirical Study of CRM for Product-Service System-Based e-Commerce in Indonesia." Procedia Computer Science, 72, 543-551.

Schmidt, G.M., and C.T. Druehl, 2008, "When is a Disruptive Innovation Disruptive?" Journal of Product Innovation Management, 25(4), 347-369.

Schoonhoven, C.B., and K.M. Eisenhardt, 1996, "Effects of Founding." Strategic Integration, 3, 365-400.

Shapiro, C., H.R. Varian, and W.E. Becker, 1999, "Information Rules: A Strategic Guide to the Network Economy." Journal of Economic Education, 30, 189-190.

Siew-Phaik L.G., A. Downe, and M. Sambasivan, 2013, "Strategic Alliances with Suppliers and Customers in a Manufacturing Supply Chain: From a Manufacturer's Perspective." Asia-Pacific Journal of Business Administration, 5(3), 192-214.

Sirmon, D.G., M.A. Hitt, R.D. Ireland, and B.A. Gilbert, 2011, "Resource Orchestration to Create Competitive Advantage: Breadth, Depth, and Life Cycle Effects. Journal of Management." 37(5): 1390-1412.

Street, C.T., and A.F. Cameron, 2007, "External Relationships and the Small Business: A Review of Small Business Alliance and Network Research." Journal of Small Business Management, 45(2), 239-266.

Suffia, S., 2017, "NoBar Online Mei: Optimalkan Pencarian Nama Produkmu dengan Belajar SEO (Search Engine Optimization).” [online] Seller Tokopedia. Available at: https://seller.tokopedia.com/2017/05/24/nobar-online-mei-optimalkan-pencarian -nama-produkmu-dengan-belajar-seo-search-engine-optimization/ [Accessed 17 Nov. 2017].

Sugianto, D., 2016, "CEO Go-Jek Berbagi 3 Tips Rayu Perbankan: Okezone Economy." [online] https://economy.okezone.com/. Available at: https://economy. okezone.com/read/2016/08/30/320/1476903/ceo-go-jek-berbagi-3-tips-rayuperbankan [Accessed 15 Nov. 2017].

Sukoco, B.M., 2016, "The Effects of Convergence and Divergence Alliance Portfolio on Firm Performance.” International Journal of Business, 21(2), 112-131.

Sukoco, B.M., 2015, "Interrelatedness, Interdependencies, and Domain Learning in Alliance Portfolios.” International Journal of Business, 20(2), 160-177.

Sukmana, Y., 2017, "Pengunjung Sepi, Pedagang Mangga Dua Mall Keluhkan Toko Online." [online] KOMPAS.com. Available at: http://ekonomi.kompas.com/ $\mathrm{read} / 2017 / 09 / 16 / 164412926 /$ pengunjung-sepi-pedagang-mangga-dua-mallkeluhkan-toko-online [Accessed 17 Nov. 2017].

Teece, D.J., 2007, "Explicating Dynamic Capabilities: The Nature and Microfoundations of (Sustainable) Enterprise Performance." Strategic Management Journal, 28(13), 1319-1350.

Teece, D. J., 1980, "Economies of Scope and the Scope of the Enterprise." Journal of Economic Behavior, and Organization, 1(3), 223-247.

Todeva, E., and D. Knoke, 2005, "Strategic Alliances and Models of Collaboration." Management Decision, 43(1), 123-148. 
Tokopedia.com., 2017a, "Pinjaman Uang Online Tanpa Jaminan - Dana Tunai Cepat." [online] Available at: https://www.tokopedia.com/pinjaman-online/ [Accessed 17 Nov. 2017].

Tokopedia, 2017b, "Gold Merchant." [online] Available at: https://gold.tokopedia.com/ [Accessed 17 Nov. 2017].

Tokopedia Blog, 2017a, "Official Account Tokopedia Kini Hadir di LINE - Tokopedia Blog." [online] Available at: https://www.tokopedia.com/blog/line-officialaccount-tokopedia/ [Accessed 17 Nov. 2017].

Tokopedia Blog, 2017b, "TravelersBox dan Tokopedia Bersinergi Mudahkan Wisatawan Indonesia di Luar Negeri - Tokopedia Blog." [online] Available at: https://www.tokopedia.com/blog/travelersbox-dan-tokopedia-bersinergimudahkan-wisatawan-indonesia-di-luar-negeri/ [Accessed 17 Nov. 2017].

Wernerfelt, B., 1984, "A Resource-based View of the Firm." Strategic Management Journal, 5(2), 171-180.

Wegner, P., 1998, "Interactive Foundations of Computing." Theoretical Computer Science, 192(2), 315-351.

Yasa, A., 2017, "Laman Kota Jakarta Hadir di Tokopedia." [online] Industri.bisnis.com. Available at: http://industri.bisnis.com/read/20170508/105/ 651724/laman-kota-jakarta-hadir-di-tokopedia [Accessed 17 Nov. 2017]. 